\title{
Implikasi Covid Dengan Pemanfaatan Digital Marketing Terhadap Pendapatan Pelaku Usaha Kuliner Disekitar Obyek Wisata Pantai Pandanan Lombok Utara
}

\author{
Tama Krisnahadi \\ Prodi Manajemen Universitas Pendidikan Mandalika \\ email: tama.wahda@gmail.com
}

\begin{abstract}
Abstrak: Penelitian ini bertujuan untuk mengetahui implikasi covid dengan pemanfaatan digital marketing terhadap pendapatan pelaku usaha disekitar obyek wisata Pantai Pandanan Kabupaten Lombok Utara. Penelitian ini menggunakan metode penelitian kualitatif. Analisis data yang digunakan adalah deskriptif kualitatif yaitu teknik penelitian yang menggambarkan dan menjelaskan data-data yang telah dikumpulkan dengan memperhatikan dan merekam sebanyak mungkin aspek yang diteliti sehingga mendapatkan gambaran secara menyeluruh tentang kondisi yang sebenarnya. Langkah-langkah analisis data kualitatif pada penelitian ini yaitu: pengumpulan data, pereduksian data, penyajian data, dan penarikan simpulan. Hasil dari penelitian menunjukkan bahwa implikasi dari pandemic covid sangat berpengaruh terhadap pendapatan pelaku usaha kuliner pada obyek wisata pantai pandanan dimana $85 \%$ dari total pelaku usaha mengalami penurunan pendapatan dan hanya $15 \%$ yang mampu mempertahankan pendapatan di tengah pandemic bahkan dapat meningkatkan pendapatannya dengan cara memanfaatkan digital marketing serta meningkatkan pelayanan dan kualitas dari produk kuliner mereka.
\end{abstract}

Kata kunci: Pendapatan, Pelaku usaha UMKM, Covid 19

\section{PENDAHULUAN}

Pandemi Covid-19 yang terjadi belakangan ini semakin memperihatinkan dimana baik PPTG, ODP, PDP semakin bertambah hal ini mengakibatkan penurunan pendapatan bagi para pelaku usaha terutama yang bergerak pada sektor pariwisata salah satunya adalah pelaku usaha kuliner disekitar obyek wisata. Menurut data update terakhir per tanggal 23 juli 2020 jumlah Pelaku Perjalanan Tanpa Gejala (PPTG) berjumlah 69446, Orang Tanpa Gejala (OTG) berjumlah 14803, Orang Dalam Pemantauan (ODP) berjumlah 7045 dan Pasien Dalam Pengawasan berjumlah (PDP) 2430 https://corona.ntbprov.go.id/list-data.

Secara keseluruhan International
Monetary Fund (IMF) memprediksikan perekonomian global akan tumbuh minus di angka 3\% diseluruh dunia. Dengan demikian pandemic ini akan memiliki dampak yang cukup signifikan terhadap pariwisata, sektor perdagangan, industri termasuk Pelaku Usaha Mikro, Kecil dan Menengah (UMKM). Data dari kementrian koperasi dan Usaha kecil
Menengah (UKM) menunjukkan pada tahun 2018 terdapat 64.194.057 UMKM yang ada di Indonesia dan mempekerjakan 116.978.631 tenaga kerja. Indonesia didominasi oleh UMKM yang menjadi tulang punggung perekonomian nasional juga terdampak serius bukan hanya pada aspek produksi dan pendapatan mereka saja, namun juga pda jumlah tenaga kerja yang harus dikurangi dikarenakan pandemi ini (Pakpahan, 2020).

Seiring dengan pemberlakukan PSBB (Pembatasan Sosial Berskala Besar) dan penerapan Work From Home (WFH) untuk karyawan baik swasta maupun pemerintah berpengaruh pada kinerja Usaha Mikro Kecil dan Menengah termasuk pelaku usaha kuliner di kawasan wisata pantai pandanan Dengan adanya PSBB maka pendapatan yang diterima pelaku usaha kuliner di kawasan obyek wisata pantai pandanan menurun drastis hal ini disebabkan peraturan pemerintah untuk menutup objek wisata dengan alasan sosial distancing dan yang diperbolehkan hanyalah go-food (order makanan). Dimana dengan keterbatasan 
pengetahuan dan teknologi yang dimiliki para pelaku usaha kuliner ini mengakibatkan penurunan pendapatan yang siginifikan.

\section{Rumusan Masalah}

Rumusan masalah dalam penelitian ini adalah Untuk mengetahui implikasi covid terhadap pendapatan pelaku usaha kuliner pada obyek wisata pantai pandanan Kabupaten Lombok Utara.

\section{METODE PENELITIAN}

Penelitian ini menggunakan metode penelitian kualitatif. Menurut Bogdan dan Taylor (dalam Moleong, 2013: 4) mendefinisikan penelitian kualitatif sebagai prosedur penelitian yang menghasilkan data deskriptif berupa kata-kata tertulis atau lisan dari orang-orang dan perilaku orang yang diamati dengan penjelasan secara terperinci tentang permasalahan yang berhubungan dengan teori dan data yang ada, sehingga mendapat suatu kesimpulan.

Adapun informan pada penelitian berjumlah 6 orang yang terdiri dari 5 pelaku usaha kuliner pada obyek wisata pantai pandanan dan 1 orang yang berasal dari perangkat desa pandanan.

Analisis data yang digunakan adalah deskriptif kualitatif yaitu teknik penelitian yang menggambarkan dan menjelaskan data-data yang telah dikumpulkan dengan memperhatikan dan merekam sebanyak mungkin aspek yang diteliti sehingga mendapatkan gambaran secara menyeluruh tentang kondisi yang sebenarnya (Creswell, 2016). Langkah-langkah analisis data kualitatif pada penelitian ini yaitu: pengumpulan data (data collection), pereduksian data (data reduction), penyajian data (data display), dan penarikan simpulan (conclusion drawing/verification).

Untuk menetapkan keabsahan data diperlukan teknik pemeriksaan. Pelaksanaan teknik pemeriksaan pada penelitian ini didasarkan atas sejumlah kriteria tertentu. Ada empat kriteria yang digunakan yaitu, derajat kepercayaan, keteralihan, kebergantungan dan kepastian.
1. Derajat kepercayaan

Pada dasarnya menggantikan konsep validitas internal dari nonkualitatif. Derajat kepercayaan ini berfungsi untuk melaksanakan inkuri sedemikian rupa sehingga tingkat kepercayaan penemuannya dapat dicapai dan mempertunjukkan derajat kepercayaan hasil-hasil penemuan dengan jalan pembuktian oleh peneliti pada kenyataan ganda yang sedang diteliti.

2. Keteralihan

Keteralihan sebagai persoalan empiris bergantung pada kesamaan antara konteks pengirim dan penerima. Untuk melakukan pengalihan tersebut seorang peneliti hendaknya mencari dan mengumpulkan kejadian empiris tentang kesamaan konteks. Dengan demikian peneliti bertanggungjawab untuk menyediakan data deskriptif secukupnya jika ia ingin membuat keputusan tentang pengalihan tersebut.

3. Kebergantungan

Kebergantungan merupakan substitusi istilah reliabilitas dalam penelitian yang nonkualiatif. Pada cara nonkualitatif, reliabilitas ditunjukkan dengan jalan mengadakan replikkasi studi. Jika dua atau beberapa kali diadakan pengulangan suatu studi dalam suatu kondisi yang sama dan hasilnya secara esensial sama, maka dikatakan reliabilitasnya tercapai.

4. Kepastian

Kepastian berasal dari konsep objektivitas menurut nonkualitatif. Nonkualitatif menetapkan objektivitas dari segi kesepakatan antar subjek. Disini pemastin bahwa sesuatu itu objek atau tidak bergantung pada persetujuan beberapa orang terhadap pandangan, pendapat, dan penemuan seseorang. Dapat dikatakan bahwa pengalaman sesorang itu subjektif sedangkan jika disepakati oleh beberapa atau banyak orang barulah dapat dikatakan objektif. Jadi objektivitas-subjektivitasnya suatu hal bergantung pada seseorang. 


\section{HASIL DAN PEMBAHASAN}

Berdasarkan data resmi Pemerintah Daerah Nusa Tenggara Barat melalui press release per tanggal 23 Juli 2020 jumlah kasus covid-19 di Nusa Tenggara Barat yang sudah terkonfirmasi adalah sebanyak 1850 kasus (https://corona.ntbprov.go.id/). Pandemi Covid19 tidak hanya menimbulkan krisis kesehatan secara global, namun juga memberikan dampak yang signifikan di sektor ekonomi. Sejak pemerintah Indonesia menerapkan kebijakan social distancing atau physical distancing dalam merespon wabah Covid-19, bukan hanya terjadi penurunan pasien yang terdampak covid akan tetapi mengakibatkan penurunan aktivitas ekonomi yang berdampak pada penurunan pendapatan masyarakat pada umumnya..

Salah satu contohnya pada saat ini adalah hampir seluruh pelaku usaha kuliner pada objek wisata pantai pandanan yang biasanya ramai menjadi sepi sebagai akibat penurunan wisatawan yang berkunjung di pantai pandanan, karena diterapkannya social distancing atau physical distancing untuk mengurangi penyebaran virus corona yang semakin meningkat.

Kesulitan yang dihadapi oleh pekerja pada sektor informal di Provinsi Nusa Tenggara Barat pada saat pandemi Covid-19, dalam hal ini yang menjadi latar belakang penelitian yang dilakukan adalah pendapatan pelaku usaha kuliner pada objek wisata pantai pandanan. Pada penelitian ini peneliti menggunakan metodi studi kasus kualitatif, dalam proses pengambilan data untuk mendapatkan informasi akibat dari pandemi Covid-19. Di tengah berlangsungnya pandemi, peneliti melakukan wawancara secara online atau melalui telepon dengan informan penelitian .

Analisis dan interpretasi data merupakan bagian yang paling kritis dari penelitian kualitatif. Adapun yang menjadi pedoman analisis data tematik (Creswell, 2009) yang akan digunakan. Ini dianggap yang paling tepat untuk setiap penelitian yang berupaya mengeksplorasi beberapa interpretasi dari bebrapa informan yang terlibat pada penelitian ini. Dalam analisis tematik "semua kemungkinan interpretasi yang diperoleh adalah mungkin". Pemilihan di dalam memilih analisis tematik adalah bahwa pendekatan tematik yang ketat dapat menghasilkan analisis mendalam yang dapat menjawab pertanyaan penelitian tersebut (Braun dan Clarke, 2006). Informan pada penelitian ini berjumlah 6 orang yang terdiri dari5 orang pelaku usaha kuliner dan 1 orang yang berasal dari perangkat desa setempat. Adapun wawancara yang dilakukan pada penelitian ini adalah semi terstruktur dimana daftar pertanyaan yang dgunakan untuk wawancara dikembangkan berdasarkan literature yang ada. Metode pengumpulan data adalah dengan menggunakan data primer dan sekunder dimana wawancara dilakukan dengan cara semi-terstruktur. Sedangkan data sekunder diperoleh berdasarkan refernsi yang ada. Penelitian ini hanya terbatas pada 6 orang informan yang berdomisili di Desa Pandanan Kabupaten Lombok Utara. Penelitian ini adalah studi kasus eksplorasi dan sampel dipilih menggunakan metode snowball sampling. Dalam penelitian kualitatif, teknik snowball sampling banyak digunakan. Snowball sampling adalah teknik pengambilan sampel yang awal

Tabel 1: Perbandingan Pendapatan Pelaku Usaha Kuliner Pada Obyek Wisata Pantai Pandanan dalam seminggu (dalam rupiah)

\begin{tabular}{|c|c|}
\hline $\begin{array}{c}\text { Sebelum Pandemi } \\
\text { Covid-19 }\end{array}$ & $\begin{array}{c}\text { Setelah Pandemi } \\
\text { Covid-19 }\end{array}$ \\
\hline 4.500 .000 & 6.000 .000 \\
\hline 6.000 .000 & 7.000 .000 \\
\hline 3.000 .000 & 4.500 .000 \\
\hline 6.500 .000 & 500.000 \\
\hline 7.500 .000 & 1.750 .000 \\
\hline 7.500 .000 & 4.875 .000 \\
\hline
\end{tabular}

Sumber: Wawancara.

Berdasarkan hasil penelitian umumnya banyak pelaku usaha kuliner pada kawasan wisata pantai pandanan mengalami penurunan pendapatan secara signifikan akan tetapi hal ini tidak berlaku bagi pelaku usaha yang lain yang memanfaatkan media social sebagai sarana dalam melakukan pemasaran produk mereka 
baik melalui WhatsApp maupun facebook bahkan pendapatan mereka dapat meningkat dibandingkan sebelum pandemic. Berdasarkan hasil survey pada pelaku usaha di kawasan pantai pandanan serta informasi dari perangkat desa pandanan secara menyeluruh $85 \%$ mereka mengalami penurunan dalam hal pendapatan yang diakibatkan menurunnya wisatawan yang datang ke pantai pandanan dan hanya $15 \%$ dari total pelaku usaha yang pendapatannya tetap bahkan melebihi keadaan sebelum pandemic covid dengan cara menggunakan digital marketing serta meningkatkan pelayanan dan kualitas dari produk kuliner mereka.. Di Era revolusi industri 4.0 para pelaku usaha memang seharusnya sudah bergerak ke perdagangan secara digital marketing karena pola pedagangan dan pembelanjaan dari konsumen yang sudah mulai bergeser, ditambah lagi adanya pandemic covid-19 yang menjadikan digital marketing sudah menjadi pilihan yang baik untuk para pelaku usaha untuk bisa tetap bertahan bahkan berpotensi untuk dapat menjangkau pangsa pasar baru bukan hanya terpaku pada kunjungan wisatawan dalam membeli produk mereka.

Penelitian (Hendrawan et al., 2019) menyatakan digital marketing berpengaruh positif dan signifikan dalam peningkatan kinerja penjualan UMKM. $70 \%$ Pengusaha kreatif mengatakan digital marketing akan menjadi platform komunikasi utama dalam pemasaran, dan offline store akan menjadi pelengkap, dikarenakan kemudahan dan kemampuan digital marketing dalam menjangkau lebih banyak konsumen. Hal ini juga sejalan dengan penelitian yang dilakukan oleh (Purwana et al., 2017) yang menyatakan bahwa pelaku usaha harus menumbuhkan keberanian dalam mencoba hal baru seperti digital pemasaran untuk dapat terus mengembangkan usahanya

\section{SIMPULAN}

Berdasarkan hasil penelitian dan pembahasan dapat disimpulkan bahwa pandemic covid sangat berpengaruh terhadap pendapatan pelaku usaha kuliner pada objek wisata pantai pandanan dimana terjadi penurunan pendapatan secara siginifikan sebesar $85 \%$ dan hanya sebesar $15 \%$ dari total pelaku usaha yang memanfaatkan perkembangan teknologi yang dapat mempertahankan pedapatannya bahkan meningkatkan omset pendapatannya.

\section{DAFTAR PUSTAKA}

Creswell, Jhon W. (2014). Research Design: Qualitative, Quantitative, and Mix Methode Approach. Fourth Edition. SAGE Publication.

Hendrawan, A., Sucahyowati, H., Cahyandi, K., Indriyani, \& Rayendra, A. (2019). Pengaruh

Jurnal Akuntansi \& Ekonomika, Vol. 10 No. 1, Juni 2020

Moleong, L.J. (2013). Metode Penelitian Kualitatif. Bandung: PT. Remaja Rosdakarya.

Pakpahan, A. K. (2020). COVID-19 dan Implikasi Bagi Usaha Mikro, Kecil, dan Menengah. 20(April).

Purwana, D., Rahmi, R., \& Aditya, S. (2017). Pemanfaatan Digital Marketing Bagi Usaha Mikro, Kecil, Dan Menengah (UMKM) Di Kelurahan Malaka Sari, Duren Sawit. Jurnal Pemberdayaan Masyarakat Madani (JPMM), 1(1), 117.

https://doi.org/10.21009/jpmm.001.1.0 1.

Website: https://corona.ntbprov.go.id/list-data. 